Congress writes back Reagan economies

\section{Democrats}

prepare for

\section{battle}

\section{Washington}

Members of the US Congress are digging in for a period of extended skirmishing over Mr Reagan's proposed cuts in federal support for research. Democrats are already fighting to restore many of the cuts, and in the House of Representatives at least - where they still have a majority - have already had some success. In contrast, Republicans are sticking as tightly as they can to the fiscal surgery recommended by the Office of Management and Budget (OMB).

Last week, the science and research subcommittee of the House Committee on Science and Technology voted to authorize a budget of $\$ 1,161$ million for the National Science Foundation (NSF) in the fiscal year 1982, 12 per cent more than Mr Reagan's proposed budget of $\$ 1,033$ million. As expected the committee voted to restore funding for science and engineering education. Mr Reagan's budget proposed that NSF involvement in these activities be terminated; but the subcommittee has restored $\$ 75$ million, close to the figure proposed by $\mathrm{Mr}$ Carter. It also agreed to restore $\$ 26.1$ million for research in the biological, behavioural and social sciences, another target of Mr Reagan's pruning.

Not all the subcommittee decisions went in the same direction. The members also approved a recommendation from $\mathrm{Mr}$ Allen Ertel (Democrat) to eliminate $\$ 12$ million which had been allocated for NSF's new Ocean Margin Drilling Program, initiated last year as a joint venture with the oil industry. A similar proposal to eliminate ocean margin drilling activities made by the House last year was overruled later by the Senate.

The subcommittee's recommendations on the NSF budget now go to the full science and technology committee, which will decide whether or not they should be passed intact to the floor of the House and where further opposition from Republican committee members is expected. The previous enthusiastic support for NSF by the full committee is now less certain some Democrats may vote with the Republicans (as they have already done to push through proposed reductions in earthquake research and other projects sponsored by the Federal Emergency Management Agency).

In the Republican-dominated Senate it is generally expected that action on the NSF authorization will be held to Mr Reagan's level. If so, the major debate will come when the House and the Senate meet to reconcile their approaches. These proceedings could be repeated when Congress decides how much money it wants to hand over to NSF rather than just to authorize.

A similar confrontation is brewing over the budget for energy research. President Reagan proposes major cuts in support for research into alternatives to oil and fossil fuels, such as solar and geothermal energy and alcohol fuels, arguing that these will be encouraged by proposed tax credits and that demonstration projects represent a hand-out to the private sector; in contrast he has recommended a substantial increase in funding for nuclear energy.

House Democrats are trying hard to reverse these proposals, sometimes with the assistance of Republicans who accept the economic rationality of federal investment in energy-saving technologies. The energy development subcommittee of the House Science and Technology Committee has already voted to increase the solar research budget from the $\$ 193$ million proposed by Mr Reagan to more than $\$ 500$ million, closer to Mr Carter's figures.

This proposal, if sustained by the full House of Representatives and if the Senate sticks with $\mathrm{Mr}$ Reagan's policy, is again likely to create substantial conflict. Aware of this possibility, the Department of Energy is said to be drawing up new legislation which would dramatically reduce its responsibility for developing new and renewable energy sources.

Despite Republican predictions of economic doom should the budget cuts not be approved by Congress - and threats of a presidential veto in this eventuality many individual researchers remain confident that congressional allies will help save their projects. One example is research in magnetohydrodynamics (MHD), aimed at improving the efficiency of coal-fired power stations, on which more than $\$ 400$ million of government funds has already been spent.

In its budget proposals the Reagan Administration suggests that research and development on MHD, previously scheduled to receive $\$ 60$ million in 1982 , be terminated, arguing that the demonstration of engineering feasibility should become the responsibility of the private sector. A senior OMB official explained that the agency had "agonized greatly" over whether to make the cut; but that although MHD research met two of the government's present criteria for support - high-risk research with a long lead-time - it did not meet the third - a high probability that any successes would be taken up by private utilities.

MHD engineers, however, claim that many utilities remain committed to MHD, which is predicted to increase the efficiency of electricity production from coal by 50 per cent. They point out that cuts at this stage would not make sense, as most of the money is required to cover the operation of two plants whose construction is nearing completion, at the University of Tennessee's MHD Coal-Fired Flow Facility in Tullahoma, and the Component Development and Integration Facility for which superconducting magnets are being provided through the Massachusetts Institute of Technology.

Officials in Tennessee said last week that they expected local congressmen such as Representative Albert Gore or Senator Jim Sasser to argue successfully that the funds should be restored. In other years, their confidence might have been justified. This year, with OMB defining demonstration projects in energy research as "the new

\title{
Hidden cheer culled from statistics
}

\section{Washington}

In a neat display of the power of statistics, Reagan Administration officials have estimated that, even with the proposed cutbacks, spending on basic research will increase in real terms in the fiscal year 1982. Figures prepared by the Office of Management and Budget, assisted by staff from the Office of Science and Technology Policy, predict that funds for basic research will grow by 1.5 per cent from the 1981 level. At the National Science Foundation, where the cuts have focused on science and education and social and economic research, basic research in the natural sciences would show 3 per cent real growth.

The catch to these otherwise heartening figures is that they are based on an officially-predicted inflation rate of 7.5 per cent - an optimistic forecast that assumes almost instantaneous success for Mr Reagan's economic policy.

Overall, the Office of Management and Budget expects the research and development budget for 1981 to be "a few hundred million dollars"' higher than the previously expected figure of $£ 35,600$ million, largely because cancellations in civilian research will be more than offset by a $\$ 500$ million increase in military research. The net result of Mr Reagan's proposals would be to increase research spending by about 13 per cent between 1981 and 1982 , to a total of $\$ 40,600$ million. Compared with $\mathrm{Mr}$ Carter's proposals, the research budget for the Department of Defense would be increased by an extra $\$ 1,500$ million, while the non-defence budget would be $\$ 2,200$ million less than first proposed.

David Dickson 
pork barrel"', there is more doubt.

Last week, for example, even the chairman of the House science and technology committee, Mr Donal Fuqua (Democrat) failed to persuade the members of the energy supply subcommittee to support his efforts to reinstate funds for a synthetic fuels demonstration project which faces shutdown without further federal support. Other areas in which efforts to restore funds are being made are for the Ocean Thermal Energy Conversion programmes - OTEC - described by OMB officials as being of very limited payoff - and the decision to hold back on establishing a Center for Fusion Energy and its Fusion Energy Device, both centrepieces of Mr Carter's plans for the rapid development of magnetic confinement fusion.

David Dickson

\section{UK aerospace}

\section{Eager for orders}

British industry is beginning to wake up to space communications as a commercial proposition. British Aerospace, the largest British company with a space interest, is on tenterhooks, waiting to hear whether it has won two major contracts for communications satellites. The orders at stake are for a British defence communications satellite network and for the Arab regional satellite communications system, Arabsat.

The contracts would be a watershed for the company, for it has hitherto had only the European Space Agency as a customer for sateilite systems. If its bids are now successful, it hopes to compete for similar orders in other parts of the world.

Arabsat, which is also being contested by Ford Aerospace and the Hughes Corporation, is the most crucial of the two. British Aerospace is cheered that it has appeared on the short list of three out of the five initial bidders. The Arab countries are to make a decision within four or five weeks.

Competition for the defence satellite system is not so fierce. The British government, which had been expected to award the contract at the end of March, is taking its time choosing between British Aerospace and Marconi. The plan is to order three satellites, worth a total of about $£ 100$ million, one of which will be operational at any time and which will replace the seven-year-old Skynet satellite. The company that wins will hope to gain a foothold in the NATO market.

British Aerospace's attempts to become a major supplier of telecommunications systems have also extended to setting up joint ventures with other companies. Together with Plessey, which has built satellite earth stations, it says it can offer a team capable of building complete defence communications satellite systems. It is also planning a joint venture with the US Comsat General corporation to lease military satellite communications services. And its ambition to compete for more contracts like Arabsat led it last month to set up a group called Satcom International with the French company Matra. Satcom plans to put in a bid for a regional satellite for Australia in May.

British Aerospace is selling itself on its experience. It has played a leading part in the telecommunications activities of the European Space Agency, having been the prime contractor for the series of Orbital Test Satellites and the more sophisticated European Communications Satellites. It also prides itself on being the only nonAmerican company to contribute to Comsat General's Comstar programme for long distance telephony within the United States.

Attempts to exploit the commercial potential of space may have come rather late in Britain. But the present flurry of activity is not confined to aerospace and electronics companies. The Department of Industry says that an increasing variety of organizations, from banks to pension funds, now think of telecommunications when asking where to put their money.

How matters will develop depends not only on the industry's ability to compete and fulfil its promises but also on what the British government decides. The industry is now in limbo waiting for a government response to a confidential report by the Central Policy Review Staff on the commercial exploitation of space and for the publication of a Home Office report on direct broadcast television by satellite. The reports, if nothing else, may recommend making it easier for venture capital and private enterprise to take a share of the action.

Judy Redfearn

\section{UK nuclear power \\ Battle begun}

The first shots have been fired in the impending battle about the building of a pressurized water reactor (PWR) in Britain, even though the Department of Energy has not yet decided when the proposed public inquiry will be opened. Last week, the Friends of the Earth (UK branch) issued a document subtitled "A critique of the government's nuclear power programme" (Friends of the Earth, London; £1.50) which concludes that its

Magnox at Dungeness $A$ - open soon?

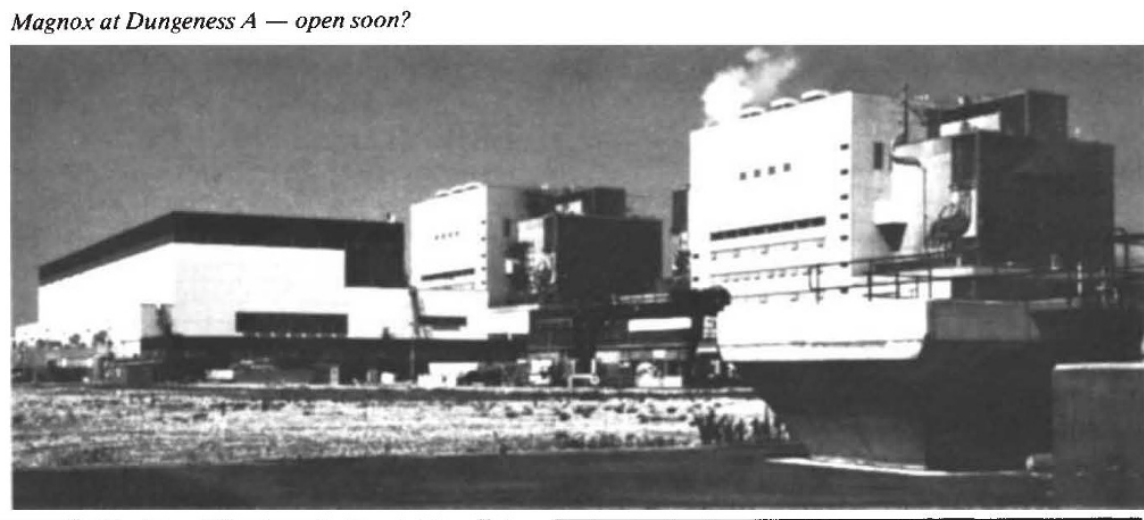

own case against the proposed reactor, to be built at Sizewell in Suffolk, on the North Sea coast, is so strong that a public inquiry is not necessary.

The argument is straightforward. First, forecasts of electricity demand in the United Kingdom, revised downwards for the past several years, are "wholly unrealistic" and are likely to be further undermined by changing patterns in the demand for electricity. Second, the cost of building the first British pressurized water reactor is likely to be twice the Electricity Generating Board's estimate (of $£ 850$ per kilowatt) while the cost of generating electricity will be magnified by the alleged low availability of reactors based on the Westinghouse design.

Third, the report (which includes a helpful account of the design changes required by the British nuclear inspectors) says that "the unique hazards of the American PWR must not be introduced into Britain". It is especially critical of a study by the nuclear inspectors of the generic safety of this type of reactor, which has not been published in full. The report also argues that "unresolved" problems concerning the safety of these reactors have not yet been resolved.

The conclusion is that Britain (and British taxpayers) would be better advised to put their money into renewable resources. Insulating lofts to a high standard would be six times as productive as building a pressurized water reactor at Sizewell, according to the Friends of the Earth.

Earlier this week, the Central Electricity Generating Board - the chief but not the only target of the Friends of the Earth had not decided whether, and if so how, to reply to the criticisms levelled at it. To the extent that some of the complaints coincide with the criticisms of the House of Commons Select Committee on Energy some weeks ago (see Nature 19 February p.621), the authors of the new report may have to wait until the formal response from the Department of Energy.

The intended public inquiry about the proposal to build a single pressurized water reactor at Sizewell is now a formal commitment by the British government. Although the form of the inquiry has not yet been settled it is likely to be generic, dealing not with the characteristics of the Sizewell site 